\title{
PENGARUH SUBSTITUSI TEPUNG IKAN TERI (STOLEPHORUS COMMERSONII) DAN TEPUNG KACANG MERAH (VIGNA ANGULARIS) TERHADAP DAYA TERIMA DAN KANDUNGAN PROTEIN PIE MINI
}

\author{
The Effect of Anchovy (Stolephorus commersonii) Flour and Red Beans (Vigna angularis) Flour \\ Substitution toward Mini Pie Acceptance and Proteins Content \\ Muhammad Nabil Faroj \\ Program Studi S1 Ilmu Gizi, Fakultas Kesehatan Masyarakat, Universitas Airlangga, Surabaya, Indonesia \\ E-mail: nabilfaroj@gmail.com
}

\begin{abstract}
ABSTRAK
Tepung ikan teri dan tepung kacang merah merupakan bahan pangan tinggi protein dan asam amino esensial yang dapat diolah menjadi berbagai jenis makanan seperti pie mini sehingga dapat dijadikan jajanan alternatif tinggi protein. Penelitian ini bertujuan untuk mengetahui pengaruh substitusi tepung ikan teri pada tepung terigu dan tepung kacang merah pada susu bubuk terhadap daya terima dan kadar protein. Penelitian pada tahap pengembangan formula ini merupakan jenis penelitian eksperimental murni dengan desain Rancangan Acak Lengkap (RAL). Terdapat 4 (empat) jenis perlakuan (substitusi tepung ikan teri dan tepung kacang merah) dengan 3 (tiga) kali pengulangan. Panelis tak terlatih yang dilibatkan sebanyak 25 orang ibu balita. Analisis statistik perbedaan daya terima menggunakan uji Kruskal Wallis dan Mann Whitney dengan $\alpha \leq 0,05$. Hasil uji organoleptik menunjukkan formula substitusi yang paling disukai panelis adalah F3 62,5g (substitusi tepung ikan teri dan tepung kacang merah 15g). Peningkatan kandungan protein tertinggi tiap $100 \mathrm{~g}$ pie mini pada F3 $(9,6)$. Terdapat perbedaan yang signifikan antara $\mathrm{F} 0$ dengan $\mathrm{F} 1, \mathrm{~F} 2$ dan F3 pada semua karakteristik (warna $\mathrm{p}=0,000$, aroma $\mathrm{p}=0,027$, tekstur $\mathrm{p}=0,002$, rasa $\mathrm{p}=0,000$ ). Komposisi formula terbaik adalah F3 (substitusi tepung ikan teri $62,5 \mathrm{~g}$ dan tepung kacang merah $15 \mathrm{~g}$ ). Pie mini yang dimodifikasi dengan tepung ikan teri dan tepung kacang merah layak menjadi jajanan alternatif tinggi protein untuk anak balita.
\end{abstract}

Kata kunci: tepung ikan teri, tepung kacang merah, pie mini, daya terima, protein

\begin{abstract}
Anchovy flour and red beans flour are food with high proteins and essential amino acid that could be processed into various foods such as mini pie which could become high-proteins snack. This research aimed to analyze the effect of anchovy flour and red beans flour substitution towards mini pie acceptance and protein content. The design of this formula development study was true experiment with completely randomized design. There were 4 types of treatment (substitution of anchovy flour and red beans flour) with 3 times of replication. There were 25 mothers of children under five involved as untrained panelists. The differences in acceptance level was analyzed by Kruskal Wallis and Mann Whitney test $(\alpha \leq 0.05)$. The result of organoleptic tests showed the most preferred formula was F3 anchovy flour $62.5 \mathrm{~g}$ and red bean flour 15g. The highest increase in proteins content substitution per $100 \mathrm{~g}$ mini pie was F3 (9,6 g). There were significant differences between FO with F1, F2, and F3 for all characteristics (colour $p=0.000$, aroma $p=0.027$, texture $p=0.002$, flavour $p=0.000$ ). The best formula composition was $F 3$ (substituted by anchovy flour $62.5 \mathrm{~g}$ and red bean flour $15 \mathrm{~g}$ ). Mini pie modified by anchovy flour and red bean flour could be functioned as an alternative high protein snack for children under five years old.
\end{abstract}

Keywords: anchovy flour, red bean flour, mini pie, acceptance, proteins 


\section{PENDAHULUAN}

Fase anak berusia dibawah dua tahun (baduta) merupakan tahapan penting dalam menunjang kualitas SDM, dimana tahapan tersebut termasuk dalam periode emas atau 1000 Hari Pertama Kehidupan. Kualitas SDM yang rendah dapat disebabkan oleh rendahnya status gizi. Salah satu masalah gizi adalah stunting akibat terhambatnya pertumbuhan dan perkembangan. Masalah gizi tersebut perlu ditanggulangi melalui pemberian makanan tambahan (Justisia dan Adi, 2016).

Program Pemberian Makanan Tambahan Pemulihan (PMT-P) merupakan strategi yang dilakukan untuk mengurangi masalah gizi kurang pada balita di Indonesia. Program tersebut merupakan pemberian suplementasi gizi untuk melengkapi kebutuhan gizi. Strategi ini termasuk dalam intervensi gizi spesifik Gerakan Nasional Percepatan Perbaikan Gizi berdasarkan Peraturan Presiden Nomor 42 Tahun 2013. Berdasarkan Kemenkes RI (2011), setiap 100 gram produk pemberian makanan tambahan pemulihan mengandung 450 kalori, $14 \mathrm{~g}$ lemak, $9 \mathrm{~g}$ protein, $71 \mathrm{~g}$ karbohidrat serta mengandung 10 vitamin (vitamin A, B1, B2, B3, B6, B12, D, E, K, dan Asam Folat) serta 7 mineral (besi, seng, fosfor, selenium, dan kalsium). Berdasarkan penelitian Retnowati, et al,. (2015), terdapat perbedaan berat badan balita sebelum dan sesudah pemberian makanan tambahan pemulihan serta adanya hubungan asupan energi dan protein dengan perubahan berat badan balita.

Program pemberian makanan tambahan pemulihan dengan kualitas dan kuantitas yang tepat sangat dibutuhkan anak usia dibawah tiga tahun sebagai upaya pemenuhan gizi harian. Produk yang selama ini diberikan hanya berupa jajanan dengan satu sumber bahan saja seperti pangan nabati, sehingga zat gizi yang dikandung kurang beragam. Keberagaman pangan ditunjukkan dengan kelengkapan komposisi dan mutu gizinya. Hermina dan Prihatini (2011) dalam penelitiannya menyebutkan bahwa anak balita berumur 24-59 bulan yang berstatus gizi normal mengonsumsi makanan yang lebih beragam dibandingkan anak stunting. Oleh karena itu diperlukan inovasi baru untuk meningkatkan gizi balita, khususnya anak dibawah usia tiga tahun (batita) melalui PMT-P berupa jajanan. Salah satu inovasi dalam mengolah produk jajanan adalah pie mini.

Pie mini merupakan jajanan pastry yang telah dikenal masyarakat. Pada umumnya, pastry berbahan dasar adonan roti dan mentega (Siregar dan Surata, 2017). Bahan pie tersebut dapat disubstitusi dengan bahan lain, hal tersebut merupakan upaya diversifikasi bahan pangan lokal yang tinggi protein seperti ikan dan kacangkacangan (Badan Ketahanan Pangan, 2012).

\section{Ikan teri (Stolephorus commersonii)} merupakan lauk mina tinggi protein, seluruh badannya dapat dikonsumsi sehingga memungkinkan penyerapan zat gizi yang maksimal. Protein teri tersusun atas beberapa macam asam amino esensial (Lasimpala, 2014). Nilai gizi yang terkandung dalam $100 \mathrm{~g}$ ikan teri yaitu energi $77 \mathrm{kkal}$, protein $16 \mathrm{~g}$, kalsium 500 $\mathrm{mg}$, fosfor $500 \mathrm{mg}$, dan besi $1 \mathrm{mg}$ (Atmarita et al., 2005). Ikan teri merupakan salah satu jenis ikan dengan ketersediaan yang melimpah. Pada tahun 2010 jumlah tangkapan ikan teri di Indonesia 
sebanyak 172.726 ton, sedangkan di Jawa Timur sebanyak 12.246 ton (Kemenkep, 2011).

Pangan sumber protein nabati diperlukan sebagai penyeimbang kandungan bahan protein hewani, seperti kacang merah (Vigna angularis). Ketersediaan kacang merah sangat melimpah dan merupakan pangan sumber protein nabati. Produksi rata-rata kacang merah sejak tahun 2009-2014 sebesar 102.000 ton (Kementan, 2015), sedangkan di Jawa Timur pada tahun 2014, produksi kacang merah sebesar 891 ton (BPS Jatim, 2015). Nilai gizi yang terkandung dalam 100 g kacang merah mengandung energi 336 kkal, protein $23,1 \mathrm{~g}$, karbohidrat 59,5 g, $80 \mathrm{mg}$ kalsium, $400 \mathrm{mg}$ fosfor, dan $5 \mathrm{mg}$ besi (Atmarita et al., 2005). Selain protein, kacang merah mengandung omega 3 lebih banyak daripada jenis kacang lainnya, yang penting untuk pertumbuhan dan fungsi otak (Yaumi, 2011). Kedua bahan tersebut dapat dijadikan tepung sebagai bahan substitusi pembuatan beberapa jenis makanan.

Berdasarkan latar belakang tersebut, diperlukan penelitian untuk mengetahui pengaruh tepung ikan teri dan tepung kacang merah serta penentuan komposisi yang tepat sehingga produk pie mini dapat diterima, layak, dan berkualitas ditinjau dari nilai uji organoleptik dan nilai gizi (protein) sebagai alternatif PMT-P.

\section{METODE}

Penelitian ini merupakan penelitian eksperimental murni (true experimental) dengan desain Rancangan Acak Lengkap (RAL). Terdapat 4 formula substitusi tepung ikan teri dan tepung kacang merah pada pembuatan pie mini dengan tiga kali pengulangan. Penelitian dilakukan pada bulan Juli 2017. Pembuatan pie mini dilakukan di Laboratorium Pengolahan Gizi Fakultas Kesehatan Masyarakat Universitas Airlangga Surabaya, sedangkan uji organoleptik dilakukan di RW V Mojo Kecamatan Gubeng Surabaya, dan uji kadar protein di Laboratorium Biokimia dan Analisis Gizi Fakultas Kesehatan Masyarakat Universitas Airlangga Surabaya.

Sampel penelitian adalah pie mini ikan teri dan kacang merah dengan formula yang telah dikembangkan. Ukuran sampel yang disajikan pada panelis adalah 12,5 $\mathrm{g}$ untuk setiap formula pie mini. Sampel diambil secara acak dari hasil pengulangan pada tiga perlakuan.

Penilaian yang dilakukan pada penelitian ini berupa penilaian daya terima dan penghitungan kadar protein. Penilaian daya terima (warna, aroma, tekstur, dan rasa) diperoleh dari penilaian panelis tak terlatih menggunakan angket uji kesukaan, sedangkan penghitungan kadar protein dihitung berdasarkan Daftar Komposisi Bahan Makanan (DKBM).

Panelis menilai sampel yang disajikan dengan nilai angket uji kesukaan meliputi warna, aroma, tekstur, dan rasa dengan 4 skala penilaian, nilai 1 untuk sangat tidak suka, 2 untuk tidak suka, 3 untuk suka, dan 4 untuk sangat suka. Panelis pada penelitian ini adalah panelis tidak terlatih, yaitu ibu balita di RW 5 Mojo Kecamatan Gubeng sebanyak 25 orang. Hasil uji daya terima diolah dan dianalisa untuk mengetahui formula dengan nilai daya terima paling tinggi. Uji Kruskal Wallis $\alpha \leq 0,05$ digunakan untuk mengetahui perbedaan pengaruh substitusi tepung ikan teri dan tepung kacang merah terhadap daya terima pie mini, sedangkan uji Mann Whitney $\alpha \leq$ 
0,05 digunakan untuk mengetahui perbedaan tiap formula. Formula dengan nilai daya terima paling tinggi diuji kadar proteinnya di laboratorium biokimia dan analisis gizi menggunakan metode kjeldahl.

Bahan yang digunakan dalam pembuatan pie mini ikan teri dan kacang merah adalah tepung ikan teri, tepung kacang merah, tepung terigu, margarin, gula bubuk, telur, susu bubuk, tepung maizena, dan gula pasir. Formulasi pie mini ikan teri dan kacang merah disajikan pada Tabel 1.

Tabel 1. Formula Pie Mini Ikan Teri dan Kacang Merah

\begin{tabular}{|c|c|c|c|c|}
\hline \multirow[b]{2}{*}{ Komposisi (g) } & \multicolumn{4}{|c|}{ Formula } \\
\hline & F0 & F1 & $\mathrm{F} 2$ & F3 \\
\hline \multicolumn{5}{|l|}{ Kulit Pie Mini } \\
\hline $\begin{array}{l}\text { Tepung ikan } \\
\text { teri }\end{array}$ & 0 & 62,5 & 50 & 62,5 \\
\hline Tepung terigu & 250 & 187,5 & 200 & 187,5 \\
\hline Gula bubuk & 75 & 75 & 75 & 75 \\
\hline Margarin & 150 & 150 & 150 & 150 \\
\hline \multicolumn{5}{|l|}{ Fla Pie Mini } \\
\hline Telur & 25 & 25 & 25 & 25 \\
\hline $\begin{array}{l}\text { Tepung kacang } \\
\text { merah }\end{array}$ & 0 & 7,5 & 15 & 15 \\
\hline Susu bubuk & 30 & 22,5 & 15 & 15 \\
\hline Gula pasir & 60 & 60 & 60 & 60 \\
\hline Maizena & 30 & 30 & 30 & 30 \\
\hline \multicolumn{5}{|l|}{ Keterangan: } \\
\hline \multicolumn{5}{|c|}{$\begin{array}{l}\text { F0: tepung ikan teri } 0 \mathrm{~g} \text {, tepung terigu } 250 \mathrm{~g} \text {, tepung } \mathrm{kc} \text {. } \\
\text { merah } 0 \mathrm{~g} \text {, susu bubuk } 30 \mathrm{~g}\end{array}$} \\
\hline \multicolumn{5}{|c|}{$\begin{array}{l}\text { F1: tepung ikan teri } 62,5 \mathrm{~g} \text {, tepung terigu } 187,5 \mathrm{~g} \text {, tepung } \mathrm{kc} \text {. } \\
\text { merah } 7,5 \mathrm{~g} \text {,susu bubuk } 22,5 \mathrm{~g}\end{array}$} \\
\hline \multicolumn{5}{|c|}{$\begin{array}{l}\text { F2: tepung ikan teri } 50 \mathrm{~g} \text {, tepung terigu } 200 \mathrm{~g} \text {, tepung kc. } \\
\text { merah } 15 \mathrm{~g} \text {, susu bubuk } 15 \mathrm{~g}\end{array}$} \\
\hline \multicolumn{5}{|c|}{$\begin{array}{l}\text { F3: tepung ikan teri } 62,5 \mathrm{~g} \text {, tepung terigu } 187,5 \mathrm{~g} \text {, tepung kc. } \\
\text { merah } 15 \mathrm{~g} \text {, susu bubuk } 15 \mathrm{~g}\end{array}$} \\
\hline
\end{tabular}

Tepung ikan teri disubstitusikan terhadap tepung terigu sebagai bahan campuran kulit pie mini, sedangkan tepung kacang merah disubstitusikan terhadap susu bubuk sebagai bahan campuran fla. Dasar substitusi kedua bahan tersebut dikarenakan memiliki karakteristik yang sama tetapi dengan kandungan protein yang lebih tinggi.
Proses pembuatan pie mini terdiri dari dua tahap, yaitu persiapan dan pengolahan. Persiapan dimulai dengan penepungan ikan teri dan kacang merah terlebih dahulu. Ikan teri segar dicuci dan direndam dalam air jeruk nipis serta jahe selama 30 menit untuk menghilangkan aroma amis, kemudian dilakukan pemisahan antara kepala dan badan ikan sekaligus pengeluaran isi perut. Badan dan kepala yang telah terpisah ditiriskan pada nampan alumunium yang telah dilapisi kertas teflon guna menghindari adanya perlengketan ikan pada nampan. Pengeringan dilakukan dengan panas buatan dalam oven suhu $60^{\circ} \mathrm{C}$ selama 26 jam sampai kering. Ikan kering digiling menjadi tepung sampai halus. Proses penepungan pada prinsipnya sama dengan penepungan kacang merah, tetapi tidak dilakukan perendaman dengan air jeruk nipis dan jahe serta waktu pengeringan lebih singkat (14 jam).

Proses pengolahan dimulai dengan pembuatan kulit pie dengan mencampurkan tepung ikan teri, tepung terigu, dan gula bubuk. Campuran tersebut ditambahkan mentega sambil diaduk hingga menggumpal, kemudian ditambahkan telur sedikit demi sedikit sambil diaduk hingga terbentuk adonan. Adonan ditimbang setiap $20 \mathrm{~g}$ dan dicetak bulat pada cetakan $6 \mathrm{~cm}$. Adonan dipanggang pada suhu $220^{\circ} \mathrm{C}$ selama 10 menit dan $150^{\circ} \mathrm{C}$ untuk 5 menit selanjutnya. Adapun fla dibuat dengan memasak tepung kacang merah, susu bubuk, gula pasir, tepung maizena, dan air di atas panci dengan api sedang. Semua bahan tersebut diaduk hingga mengental. Setelah mengental, fla dituangkan ke atas kulit pie mini. 
Penelitian ini melibatkan manusia sebagai subjek, yaitu panelis untuk menilai daya terima produk. Penelitian ini telah mendapat persetujuan Komisi Etik Penelitian Kesehatan, Fakultas Kesehatan Masyarakat, Universitas Airlangga, Surabaya.

\section{HASIL DAN PEMBAHASAN}

Hasil uji organoleptik oleh panelis tidak terlatih terhadap tingkat kesukaan warna pie mini disajikan pada Tabel 2. Tingkat kesukaan warna tertinggi adalah F0, sedangkan warna pie modifikasi yang paling disuksai adalah F3 dengan mean 2,64. Warna pie mini yang dinilai oleh panelis adalah keseluruhan warna pie mini, baik kulit maupun fla.

Panelis lebih menyukai warna kuning terang dengan paduan putih pada fla F0 dibandingkan formula lainnya (F1, F2, F3). Pie modifikasi berwarna lebih gelap dari keseluruhan komponen karena adanya tepung ikan teri dalam adonan kulit pie dan tepung kacang merah dalam fla. F3 (formula dengan substitusi tepung ikan teri dan tepung kacang merah terbanyak) merupakan formula yang paling disukai diantara formula substitusi lainnya karena kombinasi warna lebih tegas, tidak pucat seperti F1 maupun F2. Hal tersebut sejalan dengan penelitian Rahmawati dan
Rustanti (2013) pada pembuatan cookies substitusi tepung tempe dan tepung ikan teri dimana warna yang paling disukai adalah cookies tanpa substitusi dan substitusi bahan terbanyak (25\% tepung tempe dan $10 \%$ tepung ikan teri).

Kulit pie modifikasi berwarna coklat karena substitusi tepung ikan teri, sedangkan fla yang putih keabu-abuan merupakan hasil substitusi tepung kacang merah. Semakin banyak tepung ikan teri dan tepung kacang merah yang ditambahkan warna akan semakin kecoklatan. Pigmen coklat terbentuk sebagai akibat dari reaksi maillard, sebagai akibat kondensasi gula pereduksi bergugus karbonil dengan grup amino bebas dari asam amino, peptide, maupun protein (Catrein et al., 2008). Reaksi maillard dihasilkan dari proses pemanasan pada saat pemasakan fla dan pengovenan kulit pie.

Aroma merupakan salah satu parameter penting dalam penilaian daya terima. Hasil uji organoleptik oleh panelis tidak terlatih terhadap tingkat kesukaan aroma pie mini disajikan pada Tabel 3. Aroma pie mini F1, F2, dan F3 adalah bau khas ikan teri. F0 menunjukkan penilaian tertinggi dari semua formula, sedangkan F3 dan F1 menunjukkan penilaian tertinggi untuk aroma pie modifikasi dengan mean 2,68.

Tabel 1. Distribusi Tingkat Kesukaan Panelis terhadap Warna Pie Mini

\begin{tabular}{|c|c|c|c|c|c|c|c|c|c|c|c|}
\hline \multirow{2}{*}{$\begin{array}{c}\text { Kode } \\
\text { Sampel }\end{array}$} & \multicolumn{2}{|c|}{1} & \multicolumn{2}{|c|}{2} & \multicolumn{2}{|c|}{3} & \multicolumn{2}{|c|}{4} & \multicolumn{2}{|c|}{ Total } & \multirow{2}{*}{ Mean } \\
\hline & $\mathrm{n}$ & $\%$ & $\mathrm{n}$ & $\%$ & $\mathrm{n}$ & $\%$ & $\mathrm{n}$ & $\%$ & $\mathrm{~N}$ & $\%$ & \\
\hline F0 & 1 & 4 & 2 & 8 & 7 & 28 & 15 & 60 & 25 & 100 & 3,44 \\
\hline F1 & 0 & 0 & 12 & 48 & 13 & 52 & 0 & 0 & 25 & 100 & 2,52 \\
\hline F2 & 2 & 8 & 8 & 32 & 13 & 52 & 2 & 8 & 25 & 100 & 2,60 \\
\hline F3 & 1 & 4 & 8 & 32 & 15 & 60 & 1 & 4 & 25 & 100 & 2,64 \\
\hline
\end{tabular}


Tabel 2. Distribusi Tingkat Kesukaan Panelis terhadap Aroma Pie Mini.

\begin{tabular}{|c|c|c|c|c|c|c|c|c|c|c|c|}
\hline \multirow{2}{*}{$\begin{array}{c}\text { Kode } \\
\text { Sampel }\end{array}$} & \multicolumn{2}{|c|}{1} & \multicolumn{2}{|c|}{2} & \multicolumn{2}{|c|}{3} & \multicolumn{2}{|c|}{4} & \multicolumn{2}{|c|}{ Total } & \multirow{2}{*}{ Mean } \\
\hline & $\mathrm{n}$ & $\%$ & $\mathrm{n}$ & $\%$ & $\mathrm{n}$ & $\%$ & $\mathrm{n}$ & $\%$ & $\mathrm{~N}$ & $\%$ & \\
\hline F0 & 1 & 4 & 2 & 8 & 15 & 60 & 7 & 28 & 25 & 100 & 3,12 \\
\hline F1 & 1 & 4 & 8 & 32 & 14 & 56 & 2 & 8 & 25 & 100 & 2,68 \\
\hline F2 & 2 & 8 & 9 & 36 & 12 & 48 & 2 & 8 & 25 & 100 & 2,56 \\
\hline F3 & 1 & 4 & 8 & 32 & 14 & 56 & 2 & 8 & 25 & 100 & 2,68 \\
\hline
\end{tabular}

F0 mempunyai aroma khas mentega, sedangkan pada F1, F2, dan F3 aroma mentega tertutupi oleh aroma khas ikan teri. F1 dan F3 yang merupakan formula substitusi tepung ikan teri terbanyak menghasilkan aroma baru yang lebih tegas. Aroma yang dihasilkan bukan aroma amis, tetapi aroma khas ikan teri. Tidak terdapat perbedaan nyata kedua formula modifikasi tersebut dengan $\mathrm{F} 2(\mathrm{p}=0,570)$.

Hasil penelitian tidak menunjukkan pengaruh tepung kacang merah terhadap aroma pie mini. Sejalan dengan Rahmawati dan Rustanti (2013) pada pembuatan cookies substitusi tepung tempe dan tepung ikan teri dimana aroma paling disukai adalah formula dasar, namun formula modifikasi dengan substitusi terbesar memiliki nilai daya terima yang cukup tinggi. Zat fosfolipida berupa trimetilamin oksida (TMAO) yang terpisah membentuk trimetilamin (TMA), umumnya terjadi pada jenis ikan laut (Dharma et al., 2014). Reaksi tersebut menghasilkan aroma khas ikan, apabila reaksi terus berlanjut dapat menghasilkan aroma amis berlebih.
Karakteristik tekstur pie mini dinilai dengan membagi dan menggigit untuk mengetahui keremahan kulit pie. Tabel 4 menunjukkan tingkat kesukaan tekstur tertinggi adalah F0 dengan mean 3,16, sedangkan untuk formula modifikasi adalah F3 dengan mean 2,6.

Tekstur pie mini yang baik menurut Beranbaum (1998) adalah cukup lembut, ringan, dan flaky. Tekstur pie mini yang paling disukai panelis adalah F0. Adonan F0 menggunakan tepung terigu, sedangkan F1, F2, F3 tepung terigu disubstitusi dengan tepung ikan teri. F1 dan F3 merupakan formula substitusi ikan teri terbanyak dan tepung terigu paling sedikit, sehingga tekstur yang dihasilkan agak keras, tetapi ketika dipadukan dengan fla, kesolidan tekstur lebih baik, berbeda dengan F2 yang lebih mudah hancur ketika dipadukan dengan fla.

Kulit pie mini yang bertekstur agak keras dikarenakan substitusi tepung ikan teri terhadap tepung terigu, sehingga kadar gluten kulit yang banyak terkandung dalam terigu berkurang. Berkurangnya kadar gluten tersebut

Tabel 3. Distribusi Tingkat Kesukaan Panelis terhadap Tekstur Pie Mini

\begin{tabular}{|c|c|c|c|c|c|c|c|c|c|c|c|}
\hline \multirow{2}{*}{$\begin{array}{c}\text { Kode } \\
\text { Sampel }\end{array}$} & \multicolumn{2}{|c|}{1} & \multicolumn{2}{|c|}{2} & \multicolumn{2}{|c|}{3} & \multicolumn{2}{|c|}{4} & \multicolumn{2}{|c|}{ Total } & \multirow{2}{*}{ Mean } \\
\hline & $\mathrm{n}$ & $\%$ & $\mathrm{n}$ & $\%$ & $\mathrm{n}$ & $\%$ & $\mathrm{n}$ & $\%$ & $\mathrm{~N}$ & $\%$ & \\
\hline F0 & 0 & 0 & 3 & 12 & 15 & 60 & 7 & 28 & 25 & 100 & 3,16 \\
\hline F1 & 1 & 4 & 12 & 48 & 10 & 40 & 2 & 8 & 25 & 100 & 2,52 \\
\hline F2 & 3 & 12 & 9 & 36 & 12 & 48 & 1 & 4 & 25 & 100 & 2,44 \\
\hline F3 & 2 & 8 & 6 & 24 & 17 & 68 & 0 & 0 & 25 & 100 & 2,6 \\
\hline
\end{tabular}


Tabel 4. Distribusi Tingkat Kesukaan Panelis terhadap Rasa Pie Mini

\begin{tabular}{|c|c|c|c|c|c|c|c|c|c|c|c|}
\hline \multirow{2}{*}{$\begin{array}{c}\text { Kode } \\
\text { Sampel }\end{array}$} & \multicolumn{2}{|c|}{1} & \multicolumn{2}{|c|}{2} & \multicolumn{2}{|c|}{3} & \multicolumn{2}{|c|}{4} & \multicolumn{2}{|c|}{ Total } & \multirow[t]{2}{*}{ Mean } \\
\hline & $\mathrm{n}$ & $\%$ & $\mathrm{n}$ & $\%$ & $\mathrm{n}$ & $\%$ & $\mathrm{n}$ & $\%$ & $\mathrm{~N}$ & $\%$ & \\
\hline F0 & 0 & 0 & 1 & 4 & 9 & 36 & 15 & 60 & 25 & 100 & 3,56 \\
\hline F1 & 0 & 0 & 14 & 56 & 10 & 40 & 1 & 4 & 25 & 100 & 2,48 \\
\hline F2 & 0 & 0 & 8 & 32 & 15 & 60 & 2 & 8 & 25 & 100 & 2,76 \\
\hline F3 & 2 & 8 & 7 & 28 & 13 & 52 & 3 & 12 & 25 & 100 & 2,68 \\
\hline
\end{tabular}

mempengaruhi tekstur pie mini, dikarenakan fungsi elastisitas gluten sebagai pembentuk tekstur berongga dimana terjadi pengikatan udara dan uap air tidak termaksimalkan pada saat pemanggangan. Kandungan gluten yang rendah mengakibatkan rongga adonan yang terbentuk hanya sedikit, sehingga tekstur pie mini lebih keras (National Food Service Management Institute, 2009 dan Beranbaum, 1998).

Rasa merupakan indikator penting pada penilaian produk makanan. Tabel 5 menunjukkan tingkat kesukaan rasa tertinggi pada formula yang sama, yaitu F0 dengan mean 3,56, sedangkan tingkat kesukaan rasa tertinggi untuk formula modifikasi adalah F2 yang merupakan substitusi tepung ikan teri terendah dan tepung kacang merah tertinggi, dengan mean 2,76. Hal tersebut sejalan dengan penelitian Pitunani, et al (2016), yang menunjukkan semakin tinggi substitusi ikan teri pada cookies rasa yang dihasilkan cenderung makin tidak disukai panelis.

Rasa khas ikan teri yang gurih tidak hilang dengan penambahan tepung kacang merah dan menciptakan cita rasa baru pada pie mini. Rasa pie mini dapat berupa manis atau asin. Resep pie mini kontrol yang dibuat pada penelitian ini bercita rasa manis, sehingga dengan substitusi tepung ikan teri dan tepung kacang merah tercipta pie mini dengan kombinasi rasa manis dan gurih.

Setiap formula memiliki jumlah tepung ikan teri, tepung kacang merah, tepung terigu, dan susu bubuk yang berbeda sehingga berpengaruh pada karakteristik pie mini. Hasil analisis statistik dengan Kruskal Wallis menunjukkan adanya perbedaan yang signifikan $(\alpha \leq 0,05)$ pada semua karakteristik formula kontrol atau F0 dengan formula modifikasi (F1, F2, dan F3), tetapi tidak terdapat perbedaan signifikan $(\alpha \geq 0,05)$ antar formula modifikasi (F1 dengan F2, F1 dengan F3, dan F2 dengan F3). Substitusi bahan 10-15\% menghasilkan perbedaan karakteristik yang cukup signifikan, terutama pada bahan tepung ikan teri yang berpengaruh terhadap mutu organoleptik pie mini.

Penilaian daya terima keseluruhan terhadap karakteristik warna, aroma, tekstur, dan rasa disajikan pada Gambar 1. Formula F0 sebagai formula kontrol memiliki penilaian tertinggi seluruh karakteristik penilaian uji kesukaan, sedangkan formula F3 (tepung ikan teri 62,5 g, tepung kacang merah $15 \mathrm{~g}$, tepung terigu $187,5 \mathrm{~g}$, susu bubuk $15 \mathrm{~g}$ ) merupakan formula modifikasi yang memiliki penilaian tertinggi seluruh karakteristik penilaian uji kesukaan. Indikator lain 
agar menjadi alternatif PMT-P selain faktor daya terima adalah mengandung protein tinggi, sekurang-kurangnya 9 g per 100 g produk. Pie mini substitusi tepung ikan teri dan tepung kacang merah dapat dijadikan produk alternatif PMT-P tinggi protein. Kadar protein setiap $100 \mathrm{~g}$ pie mini berdasarkan perhitungan DKBM dan uji laboratorium disajikan pada Tabel 6.

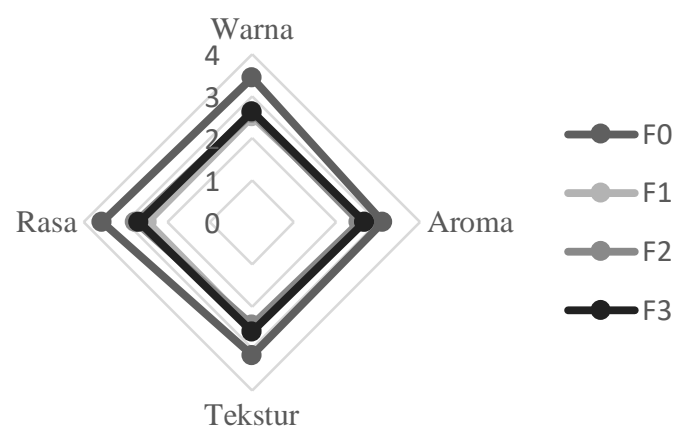

Gambar 1. Diagram Penilaian Keseluruhan Daya Terima Pie Mini

Tabel 6 menunjukkan, berdasarkan perhitungan DKBM, kandungan protein per $100 \mathrm{~g}$ pie mini terendah adalah F0 yaitu 5,63 g dan tertinggi adalah F3 yaitu 9,55. Hasil analisis laboratorium dilakukan pada formula pie mini F3 dan didapatkan nilai protein sebesar $7,28 \%$ per 100 g pie mini.

Pie mini melalui dua proses pemanasan, yaitu pengeringan ikan teri dan kacang merah dengan suhu $60^{\circ} \mathrm{C}$ selama lebih dari 12 jam dan

Tabel 6. Distribusi Kadar Protein per 100 g Pie Mini

\begin{tabular}{ccc}
\hline \multirow{2}{*}{ Formula } & \multicolumn{2}{c}{ Kandungan Protein } \\
\cline { 2 - 3 } & DKBM (g) & Laboratorium (\%) \\
\hline F0 & 5,63 & - \\
F1 & 9,54 & - \\
F2 & 8,78 & - \\
F3 & 9,55 & 7,28 \\
\hline
\end{tabular}

pemanggangan kulit pie mini dengan suhu di atas $150^{\circ} \mathrm{C}$ selama 15 menit. Pemanasan menyebabkan proses denaturasi protein, yang berarti perubahan terhadap struktur molekul protein tanpa terjadi pemecahan ikatan-ikatan kovalen (Palupi, et al., 2007). Berdasarkan penelitian Sundari, et al. (2015) proses pemanasan sebagai bagian dari pemasakan menyebabkan kadar protein menurun, tetapi di sisi lain berdampak pada peningkatan daya cerna dan daya simpan protein (Palupi et al., 2007).

Pie mini tepung ikan teri dan tepung kacang merah merupakan jajanan sehat tinggi protein yang dapat dijadikan alternatif PMT-P. Berdasarkan hasil perhitungan DKBM, pie mini dengan protein tertinggi adalah F3 yaitu 9,55 g per 100 g. Kandungan protein tersebut sudah memenuhi ketentuan minimum mutu pie menurut SNI 01-2973-1992 yaitu sebesar 9\%.

Kandungan protein yang tinggi pada formula pie mini modifikasi F3 dihasilkan dari substitusi tepung ikan teri terhadap tepung terigu dan tepung kacang merah terhadap susu bubuk dengan jumlah terbanyak. Kandungan protein F2 tidak sebanyak F1 dan F3 dikarenakan jumlah substitusi tepung ikan teri terhadap tepung terigu paling kecil. Adapun substitusi tepung kacang merah terhadap susu bubuk tidak terlalu banyak menghasilkan tambahan protein, namun dapat memperkaya jenis asam amino yang terkandung dalam pie mini.

Pengolahan pangan berbasis bahan pangan lokal seperti ikan teri dan kacang merah dapat meningksatkan nilai guna bahan pangan tersebut, selain itu nilai gizi yang terdapat pada pangan yang dibuat dengan bahan pangan lokal 
menjadi semakin baik. Kombinasi protein nabati dan hewani akan mempengaruhi peningkatan mutu protein, yang mana kedua jenis protein tersebut dapat saling melengkapi kandungan asam amino dari masing-masing jenis bahan (Tejasari, 2005). Protein sangat dibutuhkan oleh balita untuk sintesis jaringan baru pada masa pertumbuhan (Adriani dan Wirjatmadi, 2014).

\section{KESIMPULAN DAN SARAN}

Substitusi tepung ikan teri dan tepung kacang merah berpengaruh pada daya terima pie mini. Hasil uji organoleptik pie mini terhadap warna, aroma, tekstur, dan rasa yang paling disukai adalah formula kontrol (F0), sedangkan formula modifikasi dengan daya terima yang paling tinggi untuk warna dan tekstur adalah F3, untuk aroma adalah $\mathrm{F}$ 1 dan $\mathrm{F}$ 3, serta untuk rasa adalah F2. Kadar protein per 100 g pie mini tertinggi adalah F3 (substitusi tepung ikan teri dan tepung kacang merah) yaitu 9,55 g. Komposisi terbaik adalah formula pie mini F3 terdiri dari tepung ikan teri $62,5 \mathrm{~g}$, tepung kacang merah 15 $\mathrm{g}$, tepung terigu 187,5, dan susu bubuk $15 \mathrm{~g}$.

Pie mini substitusi tepung ikan teri dan tepung kacang merah dapat dijadikan alternatif jajanan tinggi protein karena memenuhi kebutuhan harian gizi anak dibawah usia tiga tahun dengan mengonsumsi 1,5 keping atau 37,5 g pie mini per hari (mengandung $158 \mathrm{kkal}$ energi dan 3,6 protein).

\section{DAFTAR PUSTAKA}

Adriani, M., \& Wirjatmadi, B. (2014). Peranan gizi dalam siklus kehidupan. Jakarta: Kencana Prenada Media Group.

Atmarita, Mahmud, \& Mien, K., et al., (2005). Daftar Komposisi Bahan Makanan (DKBM). Malang: Sagung Seto.
Beranbaum, R. L., (1998). The pie and pastry bible. New York, US: Scribner.

Badan Ketahanan Pangan. (2012). Roadmap diversifikasi pangan 2011-2015 Edisi 2. Kementrian Pertanian RI.

BPS Jatim. (2015). Jawa Timur dalam angka. CV. Media Konstruksi.

BSNI. (1992). SNI 01-2973-1992: Biskuit. Jakarta: BSNI.

Catrein, Surya, Y. S., \& Ertanto, T. (2008). Reaksi maillard pada produk pangan (Karya Tulis Institut Pertanian Bogor, Bogor). Retrieved from http://repositry.ipb.ac.id/handle/12345678 9/32771

Dharma, M. A., Darmanto, Y. S., \& Riyadi, P. H. (2014). Pengaruh perbedaan konsentrasi tepung kentang (solanun tuberosum) terhadap karakteristik pasta dari ikan air tawar, payau, dan laut. Jurnal Pengolahan dan Bioteknologi Hasil Perikanan, 3(3), 75-81.

Hermina, \& Prihatini, S., (2011). Gambaran keragaman makanan dan sumbangannya terhadap konsumsi energi protein pada anak balita pendek (stunting) di Indonesia. Buletin Penelitian Kesehatan, 39(2), 62-73.

Justisia, S. R., \& Adi, A. N. (2016). Mutu organoleptik, kadar protein, dan nilai ekonomi nugget substitusi ikan lele (larias batrachus) dan kacang merah (vigna angularis) sebagai snack batita. Jurnal Media Gizi Indonesia, 11(1), 106-112.

Kemenkes RI. (2011). Panduan Penyelenggaraan Pemberian Makanan Tambahan Pemulihan Bagi Balita Gizi Kurang. Jakarta: Ditjen Bina Gizi dan Kesehatan Ibu dan Anak Kemenkes RI.

Kemenkes RI. (2013). Peraturan Mentri Kesehatan (PERMENKES) no. 75 Tahun 2013 tentang Angka Kecukupan Gizi $(A K G)$. Jakarta.

Kemenkep RI. (2011). Statistik perikanan tangkap Indonesia. Jakarta: Direktorat Jendral Perikanan Tangkap.

Kementan RI. (2015). Daftar statistik pertanian hortikultura (SPH). Jakarta: Direktorat Jenderal Hortikultura.

Lasimpala, R. (2014). Uji mutu ikan teri kering pada lama pengeringan berbeda (Thesis). Universitas Negeri Gorontalo, Gorontalo. Retrieved from http://eprints.ung.ac.id/6433/. 
National Food Service Management Institute. (2009). Culinary techniques for healthy school meals (2nd ed.). Mississippi, US: University of Mississippi.

Palupi, N. S., Zakaria, F. R., \& Prangdimurti, E. (2007). Pengaruh pengolahan terhadap nilai gizi pangan. Modul e-learning ENBP Institut Pertanian Bogor, Bogor, Indonesia.

Pitunani, M. W., Wahyuni, S., \& Isamu, K. T. (2016). Analisis proksimat dan organoleptik cookies substitusi daging ikan teri berbahan baku tepung keladi (xanthosoma sagittifolium) perendaman dan tepung keladi termodifikasi. Jurnal Sains dan Teknologi Pangan, 1(3), 201208.

Rahmawati, H. \& Rustanti, N. (2013). Pengaruh substitusi tepung tempe dan ikan teri nasi (Stolephorus sp.) terhadap kandungan protein, kalsium, dan organoleptik cookies. (Thesis), Universitas
Diponegoro, Semarang. Retrieved from http://eprints.undip.ac.id/41648/.

Retnowati, D. H., Syamsianah, A., \& Handarsari, E. (2015). Pengaruh pemberian makanan tambahan pemulihan terhadap perubahan berat badan balita bawah garis merah kecacingan di wilayah Puskesmas Klambu Kabupaten Grobogan. Jurnal Gizi Universitas Muhammadiyah Semarang, 4(1), 30-36.

Siregar, R., \& Surata, I. G. (2017). Gizi kulinari. Jakarta: Penerbit Buku Kedokteran ECG.

Sundari, D., Almasyhuri, \& Lamid, A. (2015). Pengaruh proses pemasakan terhadap komposisi zat gizi bahan pangan sumber protein. Media Litbangkes, 25(4), 235242.

Tejasari. (2005). Nilai gizi pangan. Yogyakarta: Graha Ilmu.

Yaumi, N. (2011). Penambahan tepung kacang merah dalam pembuatan donat dan daya terimanya. (Skripsi) Universitas Sumatera Utara, Medan, Indonesia. 